\title{
Binding of Type 3 Reovirus by a Domain of the $\sigma 1$ Protein Important for Hemagglutination Leads to Infection of Murine Erythroleukemia Cells
}

\author{
Donald H. Rubin, ** J. Denise Wetzel,"" William V. Williams, ** Jeffrey A. Cohen, ${ }^{* *}$ \\ Chaim Dworkin, and Terence S. Dermody"sin \\ ${ }^{*}$ Department of Medical Research, Veterans Affairs Hospital; ${ }^{\ddagger}$ Departments of Medicine, ${ }^{\S}$ Microbiology \& Immunology, and $"$ Pediatrics, \\ "Elizabeth B. Lamb Center for Pediatric Research, Vanderbilt Medical School, Nashville, Tennessee 37232; ** Departments of Medicine \\ and ${ }^{\ddagger}$ Neurology, University of Pennsylvania; and ${ }^{\$}$ Department of Research Medicine, Veterans Affairs Hospital, Philadelphia, \\ Pennsylvania 19104
}

\begin{abstract}
The recognition of cellular receptors by the mammalian reoviruses is an important determinant of cell and tissue tropism exhibited by reovirus strains of different serotypes. To extend our knowledge of the role of reovirus-receptor interactions in reovirus tropism, we determined whether type 1 and type 3 reovirus strains can infect cells derived from erythrocyte precursors. We found that reovirus type 3 Dearing (T3D), but not type 1 Lang, can grow in murine erythroleukemia (MEL) cells. This difference in growth was investigated by using reassortant viruses and we found that the capacity of T3D to infect MEL cells is determined by the viral cell-attachment protein, $\sigma 1$. In experiments using murine monoclonal antibodies ( $\mathrm{mAbs}$ ) that bind to different $\sigma 1$ regions, we show that T3D binding to MEL cells is inhibited by a mAb that identifies a domain important for hemagglutination (HA). We also determined that type 3 strains that can infect murine $L$ cells but do not produce $H A$ do not infect MEL cells. These results suggest that type 3 reovirus binds to and infects erythrocyte precursor cells via a $\sigma 1$ domain important for HA. Moreover, this study suggests that different domains of some viral cell-attachment proteins are used to initiate productive infections of different types of cells. (J. Clin. Invest. 1992. 90:2536-2542.) Key words: viral attachment proteins • viral receptors • erythrocytes • viral tropism • viral pathogenesis
\end{abstract}

\section{Introduction}

The process of viral infection is initiated by the attachment of the virus to receptor molecules on the surface of the target cell (1). The mammalian reoviruses have served as a useful model to define the molecular basis of viral pathogenesis (2). In several previous studies, reovirus-receptor interactions have been shown to be an important determinant of viral tropism for particular cells and tissues in an infected host (3-6). Reovirus strains of different serotypes vary in their capacity to bind receptors on some nucleated cells (7-9), and they also vary in their capacity to agglutinate different types of erythrocytes (10-12). However, the relationship of reovirus-mediated hem-

Address correspondence to Dr. Donald H. Rubin, Veterans Affairs Medical Center (151), 1310 24th Avenue South, Nashville, TN 37212. Received for publication 20 April 1992 and in revised form 18 June 1992.

The Journal of Clinical Investigation, Inc.

Volume 90, December 1992, 2536-2542 agglutination (HA $)^{1}$ to productive viral infection of nucleated cells is not well understood.

The reovirus $\sigma 1$ protein mediates the attachment of the virus to cellular receptors (13-15). It is also the viral hemagglutinin $(16,17)$ and the determinant of the serotype-specific immune response (18). Regions of $\sigma 1$ that are important for receptor recognition have been defined by studies of type 3 reovirus strains. Selected anti- $\sigma 1 \mathrm{mAbs}$ can neutralize type 3 reovirus in assays using murine fibroblast (L) cells, but do not inhibit HA; conversely, other anti- $\sigma 1 \mathrm{mAbs}$ inhibit type 3 reovirus-mediated HA, but do not neutralize (19). These observations suggest that domains important for binding to erythrocyte receptors are antigenically distinct from those important for binding to $L$ cell receptors. Studies of type $3 \sigma 1$ deletion mutants expressed in Escherichia coli (20) and studies of protease-digestion products of type $3 \sigma 1(21)$ also suggest that binding to erythrocyte receptors and $\mathrm{L}$ cell receptors are mediated by different regions of $\sigma 1$. Finally, there are studies that suggest discrete sequences in type $3 \sigma 1$ important for HA (11) are widely separated from those important for binding to $\mathrm{L}$ cell receptors (22-24). Therefore, in the case of type 3 reovirus, distinct $\sigma 1$ domains appear to be important for viral attachment to receptor molecules on different types of cells.

In this study, we investigated the capacity of reovirus strains type 1 Lang (T1L) and type 3 Dearing (T3D) to infect erythrocyte precursor cells. We found that T3D, but not T1L, can grow in murine erythroleukemia (MEL) cells. Through the use of reassortant viruses, we found that this difference in growth is determined by the $\sigma 1$ protein. Furthermore, we determined that reovirus binding to MEL cells is mediated by a $\sigma 1$ domain important for HA. These findings suggest that the binding of reovirus to erythrocyte receptors is not only important for HA, but in some cases leads to infection of nucleated cells.

\section{Methods}

Cells and viruses. Spinner-adapted L cells were grown in either suspension or monolayer cultures in Joklik's modified Eagle's MEM (Irvine Scientific, Santa Ana, CA) that was supplemented to contain 5\% FCS (Intergen Co., Biochemicals, Purchase, NY), 2 mM L-glutamine, $1 \mathrm{U}$ penicillin $/ \mathrm{ml}$, and $1 \mu \mathrm{g}$ streptomycin $/ \mathrm{ml}$ (Irvine Scientific). MEL cells, previously designated T3cl.2 (25), were grown in Hams' F12 medium (Irvine Scientific) supplemented to contain 10\% FCS, $2 \mathrm{mM}$

1. Abbreviations used in this paper: FAC, fluorescent-activated cytometry; HA, hemagglutination; MEL, murine erythroleukemia; MOI, multiplicity of infection; PFU, plaque-forming units; T1L, type 1 Lang; T3D, type 3 Dearing. 
L-glutamine, $1 \mathrm{U}$ penicillin $/ \mathrm{ml}$, and $1 \mu \mathrm{g}$ streptomycin $/ \mathrm{ml}$. Murine thymoma (R1.1) cells were grown in RPMI 1640 medium (Irvine Scientific) supplemented to contain $10 \%$ FCS, $2 \mathrm{mM}$ L-glutamine, $1 \mathrm{U}$ penicillin $/ \mathrm{ml}$, and $1 \mu \mathrm{g}$ streptomycin $/ \mathrm{ml}$. Reovirus strains T1L and T3D are laboratory stocks. We used T1L $\times$ T3D reassortant viruses, 1.HA-3 and 3.HA-1 (4); EB1, EB121, G2, H9, and H41 (26); and $\mathrm{KC1}$ (27), and field isolate strains of type 3 reovirus, clones $9,18,43$, 44,84 , and 93 (28). Purified virion preparations were prepared by using second- and third-passage $\mathrm{L}$ cell lysate stocks of twice plaquepurified reovirus (29). For some studies, reovirus was purified from third-passage $L$ cell lysate stocks by substituting ultrasonic disruption (Ultrasonic 250; Branson Sonic Power Co., Danbury, CT) for cell homogenization in a modification of previously described techniques (30). The ratio of viral particles to plaque-forming units (PFU) in the purified virion preparations was $\sim 100: 1(31)$. Purified virions were radioiodinated by the chloramine-T method (32).

Growth of viruses in MEL cells and L cells. Suspension cultures of either MEL cells or $\mathrm{L}$ cells in microcentrifuge tubes (Fisher Scientific Co., Allied Corp., Pittsburgh, PA $)\left(5 \times 10^{5}\right.$ cells per tube $)$ were infected with reovirus at a multiplicity of infection (MOI) of 2 PFU per cell. After a $1-\mathrm{h}$ adsorption period at $4^{\circ} \mathrm{C}$, the inoculum was removed by a single wash with $1 \mathrm{ml}$ of ice-cold PBS and centrifugation at $82 \mathrm{~g}$. Fresh medium, appropriate for each cell type, was then added $(1.0 \mathrm{ml}$ per tube) and the cells were transferred to six-well plates (Costar Corp., Cambridge, MA). After an incubation at $37^{\circ} \mathrm{C}$ for defined intervals, the cells were frozen and thawed twice and titrated in duplicate on $\mathrm{L}$ cell monolayers using the plaque-assay technique (30).

Binding of viruses to MEL cells and L cells as detected by fluorescent-activated cytometry $(F A C)$ analysis. Cells were centrifuged at 100 $g$ and washed twice with $1 \%$ BSA (Sigma Chemical Co., St. Louis, MO) $/ 0.1 \% \mathrm{NaN}_{3} / \mathrm{PBS}$ (FAC wash). The cells were resuspended in FAC wash at $10^{6}$ cells $/ \mathrm{ml}$, and $0.5-\mathrm{ml}$ aliquots were distributed into 12 $\times 75-\mathrm{mm}$ glass tubes (Fisher Scientific Co.). To assess the binding of reovirus to cells, $0.05-\mathrm{ml}$ aliquots of reovirus $\left(5 \times 10^{11}\right.$ particles $\left./ \mathrm{ml}\right)$ were adsorbed to either MEL cells or L cells and incubated at $4^{\circ} \mathrm{C}$ for 1 $h$. The cells were then centrifuged, washed twice with FAC wash, and resuspended in $0.1 \mathrm{ml}$ of a 1:20 dilution of rabbit antireovirus antiserum in FAC wash. After a 45 -min incubation at $4^{\circ} \mathrm{C}$, cells were centrifuged and washed as before, resuspended in $0.1 \mathrm{ml}$ of a 1:50 dilution of FITC-labeled goat anti-rabbit IgG (Sigma Chemical Co.) in FAC wash, and incubated at $4^{\circ} \mathrm{C}$ for an additional $45 \mathrm{~min}$. The cells were again centrifuged, washed, and resuspended in FAC wash, and fluorescence intensity was determined by using a flow cytometer (FACS IV ${ }^{-}$ Becton Dickinson \& Co., San Jose, CA).

Preparation of $m A b s$. Antireovirus type $3 \mathrm{mAbs}$ G5 and F4 were obtained from previously purified hybridoma culture supernatants (19). Purified $\mathrm{mAbs}$ were radioiodinated by the chloramine-T method (32). Antireovirus type 3 receptor mAb 87.92.6 (murine IgM-kappa) (33) and isotype-matched control mAb HO 13.4 (34) were grown as ascites from hybridoma cells. For mAb 87.92.6, the ascites fluid was filtered and stored at $-70^{\circ} \mathrm{C}$ before use. For $\mathrm{mAb} \mathrm{HO} 13.4$, the antibody was immunoaffinity purified as previously described $(22)$ and used at a concentration of $10 \mu \mathrm{g} / \mathrm{ml}$ in PBS. This concentration of $\mathrm{mAb}$ HO 13.4 resulted in the same amount of binding to $\mathrm{R} 1.1$ cells as $\mathrm{mAb} 87.92 .6$ ascites as detected by flow cytometry.

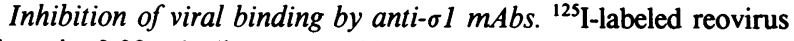
virions in $0.02-\mathrm{ml}$ aliquots $(\sim 200,000 \mathrm{cpm})$ were incubated with $0.02-\mathrm{ml}$ aliquots of $\mathrm{mAb}$-containing supernatant $(10 \mu \mathrm{g} / \mathrm{ml})$ at $23^{\circ} \mathrm{C}$ for $1 \mathrm{~h}$ in 96-well microtiter plates that had previously been treated with $2 \% \mathrm{BSA} / 0.1 \% \mathrm{NaN}_{3} / \mathrm{PBS}$. Either MEL cells or $\mathrm{L}$ cells $\left(10^{6}\right.$ cells $\left./ \mathrm{ml}\right)$ were added in $0.05-\mathrm{ml}$ aliquots and the plates were incubated at $23^{\circ} \mathrm{C}$ for an additional $30 \mathrm{~min}$. The cells were then diluted in ice-cold PBS, centrifuged, and washed three times in ice-cold PBS. Specific cpm bound was determined by subtracting cpm bound to wells similarly prepared without the addition of cells from cpm bound to wells that received cells and virus. Specific binding without inhibitor was typically $\sim 10,000 \mathrm{cpm}$ per well. The percent inhibition of virus binding by $\mathrm{mAb}$ was calculated by using the formula: $100 \times$ (Specific $\mathrm{cpm}$ bound with $\mathrm{mAb} /$ Specific cpm bound without $\mathrm{mAb}$ ).

Binding of $m A$ bs to MEL cells and R1.1 cells as detected by flow cytometry. Individual $\mathrm{mAbs}(10 \mu \mathrm{g} / \mathrm{ml})$ were added in $0.05-\mathrm{ml}$ aliquots to either MEL cells or R1.1 cells, prepared for flow cytometry as described above, and incubated at $4^{\circ} \mathrm{C}$ for $45 \mathrm{~min}$. The cells were then centrifuged and washed twice with FAC wash, and mAb binding was assessed by flow cytometry after the cells were incubated with FITC-labeled goat anti-mouse IgG (Sigma Chemical Co.).

\section{Results}

The susceptibility of $M E L$ cells to reovirus infection is determined by the viral S1 gene. Previous studies have demonstrated that reovirus strains of different serotypes exhibit distinct patterns of cell and tissue tropism in the infected host (3-6). To ascertain whether serotype-dependent differences in reovirus tropism extend to cells of the erythroid lineage, we infected erythrocyte precursor MEL cells and control L cells with either T1L or T3D. As shown in Fig. 1, these strains exhibited a striking difference: T3D, but not T1L, was found to grow in MEL cells. To determine the genetic basis for this difference in growth, we used reovirus strains containing reassorted genomes that were previously derived from crosses between T1L and T3D $(4,26,27)$. We found that reassortant viruses containing an S1 gene derived from T3D could grow in MEL cells; reassortant viruses containing an $\mathrm{S} 1$ gene derived from $\mathrm{T} 1 \mathrm{~L}$ could not grow in these cells (Table I). No other reovirus gene was associated with virus growth in MEL cells, indicating that the $\mathrm{S} 1$ gene determines the capacity of reovirus $\mathrm{T} 3 \mathrm{D}$ to infect erythrocyte precursor cells. Therefore, the capacity of reovirus to grow in MEL cells is similar to cell and tissue tropism in an infected host (3-6) in that each of these properties is determined by the viral $\mathrm{S} 1$ gene.

We next performed experiments to investigate which of the two $\mathrm{S} 1$ gene products is associated with the difference in the

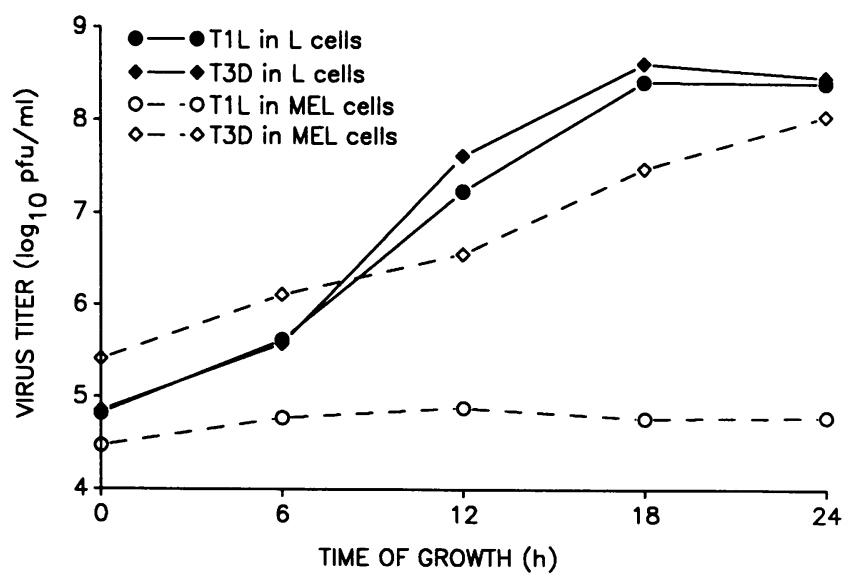

Figure 1. Growth of reovirus strains T1L and T3D in MEL cells and L cells. Either suspension cultures of MEL cells or L cells $\left(5 \times 10^{5}\right.$ cells) were infected with T1L or T3D at an MOI of 2 PFU per cell. After a $1-\mathrm{h}$ adsorption period at $37^{\circ} \mathrm{C}$, the inoculum was removed, fresh medium was added, and the cells were incubated at $37^{\circ} \mathrm{C}$. Cells were frozen and thawed twice before being titrated on $\mathrm{L}$ cell monolayers using the plaque-assay technique. The experiments were done in duplicate and the titers are presented as $\log _{10} \mathrm{PFU} / \mathrm{ml}$. 
Table I. Yield of TIL $\times T 3 D$ Reassortant Viruses in MEL Cells and L Cells

\begin{tabular}{|c|c|c|c|c|c|c|c|c|c|c|c|c|c|}
\hline \multirow{2}{*}{$\begin{array}{l}\text { Virus } \\
\text { strain }\end{array}$} & \multicolumn{10}{|c|}{ Genome segment ${ }^{*}$} & \multirow{2}{*}{$\begin{array}{l}\text { Yield in } \\
\text { MEL cells }\end{array}$} & \multirow{2}{*}{$\begin{array}{l}\text { Yield in } \\
\mathrm{L} \text { cells }\end{array}$} & \multirow{2}{*}{$\begin{array}{c}\mathrm{MEL} / \mathrm{L} \\
\text { ratio }^{8}\end{array}$} \\
\hline & L1 & L2 & L3 & M1 & M2 & M3 & S1 & S2 & S3 & S4 & & & \\
\hline T3D & D & D & D & D & D & D & D & D & D & D & $6.4 \times 10^{7}$ & $2.0 \times 10^{8}$ & 0.32 \\
\hline 1.HA-3 & $\mathrm{L}$ & $\mathrm{L}$ & $\mathrm{L}$ & $\mathrm{L}$ & $\mathrm{L}$ & $\mathbf{L}$ & D & $\mathrm{L}$ & $\mathrm{L}$ & $\mathrm{L}$ & $2.8 \times 10^{7}$ & $1.9 \times 10^{8}$ & 0.15 \\
\hline G2 & $\mathrm{L}$ & D & $\mathrm{L}$ & $\mathrm{L}$ & $\mathrm{L}$ & L & D & $\mathrm{L}$ & $\mathrm{L}$ & $\mathrm{L}$ & $1.1 \times 10^{7}$ & $9.3 \times 10^{7}$ & 0.12 \\
\hline $\mathrm{H} 9$ & D & D & $\mathrm{L}$ & $\mathrm{D}$ & $\mathrm{L}$ & $\mathrm{L}$ & D & $\mathrm{D}$ & D & D & $1.8 \times 10^{8}$ & $1.1 \times 10^{8}$ & 1.6 \\
\hline $\mathrm{KC} 19$ & L & $\mathrm{L}$ & $\mathrm{L}$ & $\mathrm{L}$ & D & L & D & L & D & $\mathrm{L}$ & $5.6 \times 10^{7}$ & $7.1 \times 10^{7}$ & 0.79 \\
\hline $\mathrm{T} 1 \mathrm{~L}$ & $\mathrm{~L}$ & $\mathrm{~L}$ & $\mathrm{~L}$ & $\mathrm{~L}$ & $\mathrm{~L}$ & L & $\mathbf{L}$ & $\mathrm{L}$ & $\mathrm{L}$ & $\mathrm{L}$ & $7.6 \times 10^{4}$ & $1.7 \times 10^{8}$ & 0.0005 \\
\hline 3.HA-1 & D & D & $\mathrm{D}$ & D & D & $\mathrm{D}$ & $\mathbf{L}$ & D & D & D & $2.9 \times 10^{4}$ & $2.5 \times 10^{7}$ & 0.0012 \\
\hline EB1 & $\mathrm{L}$ & $\mathrm{D}$ & $\mathrm{L}$ & $\mathrm{L}$ & D & L & $\mathbf{L}$ & L & D & $\mathbf{L}$ & $6.7 \times 10^{4}$ & $1.7 \times 10^{8}$ & 0.0004 \\
\hline EB121 & D & $\mathrm{D}$ & $\mathrm{L}$ & D & $\mathrm{L}$ & D & $\mathbf{L}$ & D & D & D & $2.1 \times 10^{5}$ & $9.5 \times 10^{7}$ & 0.0022 \\
\hline $\mathrm{H} 41$ & D & $\mathrm{D}$ & $\mathrm{L}$ & $\mathrm{L}$ & $\mathrm{L}$ & D & $\mathbf{L}$ & $\mathrm{D}$ & $\mathrm{D}$ & $\mathrm{L}$ & $1.0 \times 10^{5}$ & $1.0 \times 10^{8}$ & 0.0010 \\
\hline
\end{tabular}

* The parental origin of each genome segment in the reassortant strains: D, genome segment derived from T3D; L, genome segment derived from T1L $(4,26,27)$.

${ }^{\ddagger}$ Either suspension cultures of MEL cells or $\mathrm{L}$ cells $\left(5 \times 10^{5}\right.$ cells) were infected with viral strains at an MOI of 2 PFU per cell. After a 1-h adsorption period at $37^{\circ} \mathrm{C}$, the inoculum was removed, fresh medium was added, and the cells were incubated at $37^{\circ} \mathrm{C}$ for $24 \mathrm{~h}$. Cells were frozen and thawed twice before being titrated on L cell monolayers using the plaque-assay technique. The viral yields in MEL cells and L cells are expressed as the mean of four independent experiments.

${ }^{8}$ The results are expressed as the mean viral yield in MEL cells divided by that in $\mathrm{L}$ cells.

capacity of reovirus strains T1L and T3D to infect MEL cells. Given that $\mathrm{S} 1$ encodes $\sigma 1$, the viral cell-attachment protein, and $\sigma 1 \mathrm{~s}$, a nonstructural protein of unknown function (3537), we reasoned that if these strains exhibited an S1-mediated difference in their binding to MEL cells it would suggest that the difference in their growth in these cells is determined by the $\sigma 1$ protein. For these experiments we used the prototype strains T1L and T3D and the reassortant strains 1.HA-3 and 3.HA-1. These reassortant strains are single-gene reassortants that contain either the $\mathrm{S} 1$ gene of T3D and the nine remaining segments of T1L (1.HA-3) or the S1 gene of T1L and the nine remaining segments of T3D (3.HA-1) (4). Individual viral strains were adsorbed to either MEL cells or $L$ cells and virus binding was determined by flow cytometry. Although each of these strains was observed to bind L cells, only T3D and 1.HA3 could bind MEL cells (Fig. $2 A-D$ ). These results indicate that the S1 gene determines the capacity of T3D to bind MEL cells, which suggests that reovirus growth in erythrocyte precursor cells is determined by the attachment of the viral $\sigma 1$ protein to cellular receptors.

Binding of reovirus T3D to MEL cells is inhibited by an $m A b$ that inhibits T3D-mediated HA. Previous studies have suggested that different $\sigma 1$ domains are important for the binding of reovirus to receptors on different types of cells (19-21). To identify a $\sigma 1$ domain important for the binding of T3D to MEL cells, we used antireovirus type $3 \mathrm{mAbs}$ that distinguish domains important for $\mathrm{HA}$ and neutralization. The mAb F4 defines a domain important for HA in assays using either bovine or human erythrocytes; the mAb G5 defines a domain important for neutralization in assays using $L$ cells (19). To determine whether either of these domains is important for type 3 reovirus binding to MEL cells, we assessed the binding of
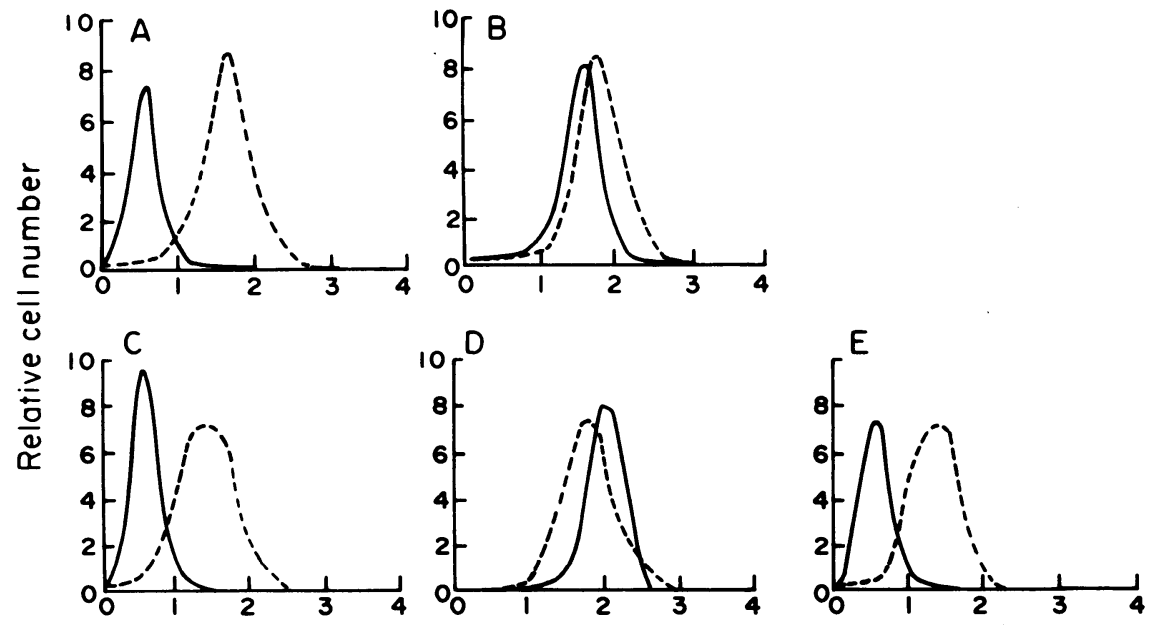

Log green fluorescence
Figure 2. Binding of reovirus strains to MEL cells and L cells. Reovirus strains T1L, T3D, 3.HA-1, 1.HA-3, or type 3 clone 44 were added to either MEL cells or L cells $\left(5 \times 10^{4}\right.$ particles per cell) and virus binding was determined by flow cytometry after the cells were incubated with rabbit antireovirus antiserum and FITClabeled goat anti-rabbit IgG. Binding by $(A)$ T1L, $(B)$ T3D, (C) 3.HA-1, (D) 1.HA-3, and (E) type 3 clone 44 to MEL cells ( solid lines) and $\mathrm{L}$ cells (dashed lines). 
A

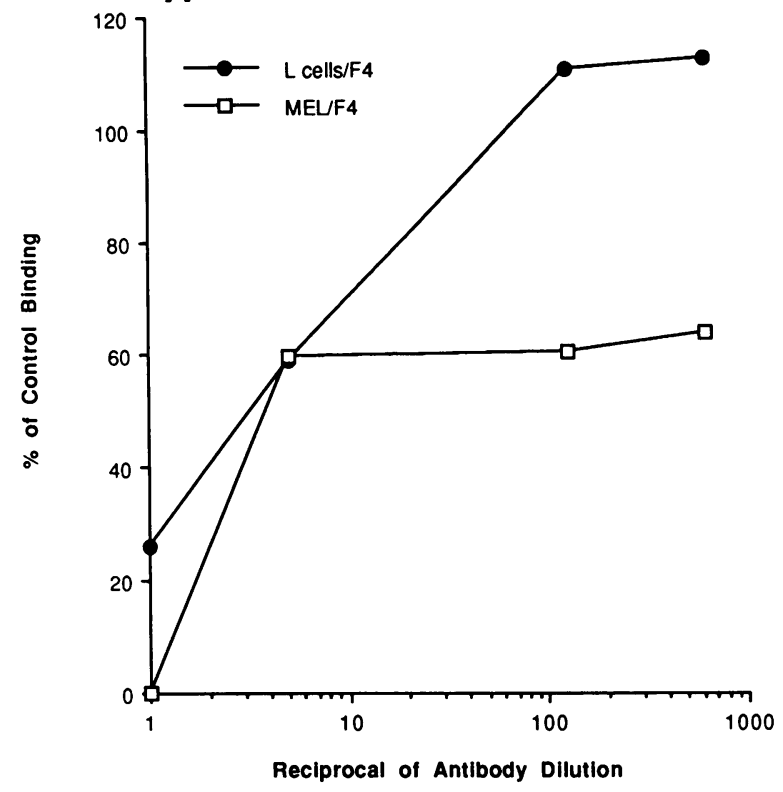

B

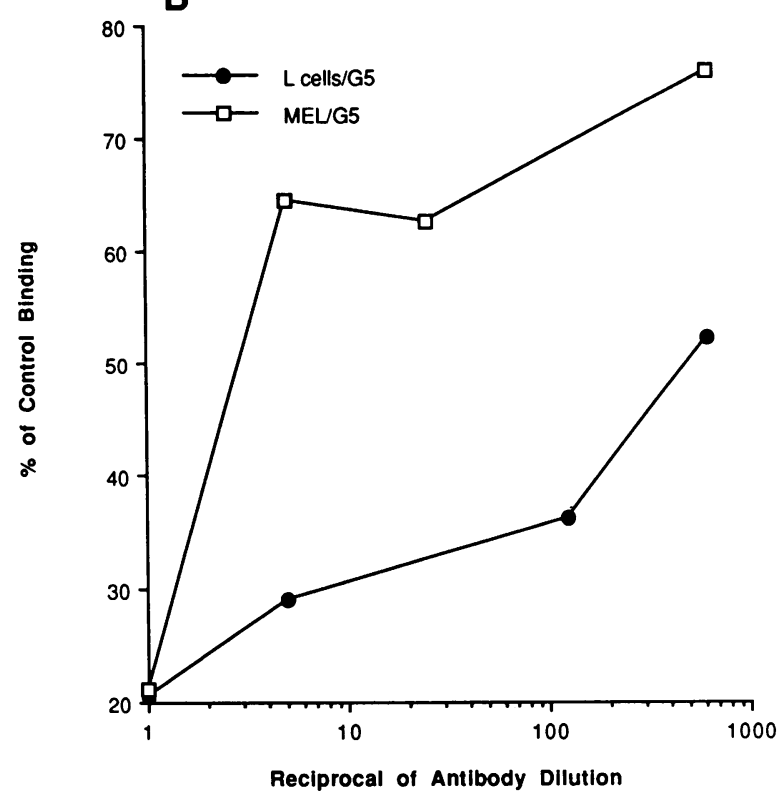

Figure 3. Inhibition of radiolabeled reovirus T3D binding to MEL cells and $\mathrm{L}$ cells by anti- $\sigma 1 \mathrm{mAbs}$. ${ }^{125} \mathrm{I}$-labeled reovirus T3D was preincubated with varying dilutions of either $(A) \mathrm{mAb}$ F4 or $(B)$ mAb G5 and then added to either MEL cells or $\mathrm{L}$ cells. The undiluted antibody concentration was $10 \mu \mathrm{g} / \mathrm{ml}$. The experiments were done in triplicate and the data are presented as the percent inhibition of virus binding by mAb.

${ }^{125}$ I-labeled T3D to MEL cells and control $\mathrm{L}$ cells after preincubation with either $\mathrm{mAb}$ F4 or mAb G5. We found that concentrated solutions of mAb F4 inhibited the binding of T3D to both MEL cells and $\mathrm{L}$ cells; however, more dilute solutions of $\mathrm{mAb} F 4$ resulted in a greater inhibition of T3D binding to MEL cells than to L cells (Fig. $3 A$ ). In contrast, mAb G5 inhibited the binding of T3D to $L$ cells to a greater extent than to MEL cells at all concentrations of antibody tested (Fig. $3 B$ ). In additional experiments using flow cytometry to detect virus attachment to cellular receptors, we found that the binding of T3D to MEL cells was also inhibited to a greater extent by $\mathrm{mAb}$ F4 than by mAb G5 (data not shown). Therefore, an anti- $\sigma 1$ mAb that inhibits T3D-mediated HA also inhibits the binding of T3D to MEL cells.

A region of $\sigma 1$ sequence important for the capacity of type 3 strains to produce HA is also important for reovirus growth in $M E L$ cells. The experiments described thus far suggest that the capacity of T3D to bind MEL cells is mediated by a $\sigma 1$ domain that plays a role in reovirus binding to erythrocytes. To gain insight into discrete sequences in type $3 \sigma 1$ that are important for viral attachment to MEL cell receptors, we used a collection of reovirus strains that vary in their capacity to produce HA and to bind sialoglycophorin A. Several type 3 strains have been previously identified that do not agglutinate either bovine or human erythrocytes and do not bind sialoglycophorincoated plates (HA negative) (11,19). A comparative analysis of the deduced $\sigma 1$ amino acid sequences of three HA-negative and eight HA-positive type 3 strains suggests that amino acids 198-204 are important for the capacity of type 3 reovirus to produce HA (11). To ascertain whether sequences important for HA are also important for viral growth in erythrocyte precursor cells, we infected either MEL cells or $L$ cells with three HA-negative and three HA-positive type 3 strains. Although the growth of these strains was found to be equivalent in L cells, the HA-negative strains did not grow in MEL cells (Table II). In additional experiments, we determined that the HA-negative strain, type 3 clone 44, did not bind MEL cells (Fig. $2 E$ ). This finding suggests that the difference in growth observed between HA-positive and HA-negative strains is caused by a

Table II. Yield of Type 3 Reovirus Strains That Vary in Their Capacity to Bind Carbohydrates in MEL Cells and L Cells

\begin{tabular}{lcccc}
\hline $\begin{array}{c}\text { Virus } \\
\text { strain }\end{array}$ & $\begin{array}{c}\text { HA } \\
\text { capacity }^{*}\end{array}$ & $\begin{array}{c}\text { Yield in } \\
\text { MEL cells }\end{array}$ & $\begin{array}{c}\text { Yield in } \\
\text { L cells }\end{array}$ & $\begin{array}{c}\text { MEL/L } \\
\text { ratiol }\end{array}$ \\
\hline T3C9 & + & $3.9 \times 10^{7}$ & $1.3 \times 10^{8}$ & 0.33 \\
T3C18 & + & $7.6 \times 10^{6}$ & $1.9 \times 10^{7}$ & 0.40 \\
T3C43 & - & $3.7 \times 10^{4}$ & $2.8 \times 10^{7}$ & 0.0013 \\
T3C44 & - & $6.2 \times 10^{4}$ & $8.9 \times 10^{7}$ & 0.0007 \\
T3C84 & - & $1.6 \times 10^{4}$ & $1.0 \times 10^{7}$ & 0.0016 \\
T3C93 & + & $5.0 \times 10^{7}$ & $4.4 \times 10^{7}$ & 1.1 \\
& & & & \\
\hline
\end{tabular}

* T3C9, type 3 clone 9; T3C18, type 3 clone 18; T3C43, type 3 clone 43 ; T3C44, type 3 clone 44 ; T3C 84 , type 3 clone 84 ; T3C 93 , type 3 clone 93.

${ }^{\ddagger}$ HA-positive type 3 strains agglutinate bovine and human erythrocytes; HA-negative type 3 strains do not (11).

${ }^{8}$ Either suspension cultures of MEL cells or $\mathrm{L}$ cells $\left(5 \times 10^{5}\right.$ cells $)$ were infected with viral strains at an MOI of 2 PFU per cell. After a 1-h adsorption period at $37^{\circ} \mathrm{C}$, the inoculum was removed, fresh medium was added, and the cells were incubated at $37^{\circ} \mathrm{C}$ for $24 \mathrm{~h}$. Cells were frozen and thawed twice before being titrated on $\mathrm{L}$ cell monolayers using the plaque-assay technique. The viral yields in MEL cells and $L$ cells are expressed as the mean of four independent experiments. "The results are expressed as the mean viral yield in MEL cells divided by that in $\mathrm{L}$ cells. 


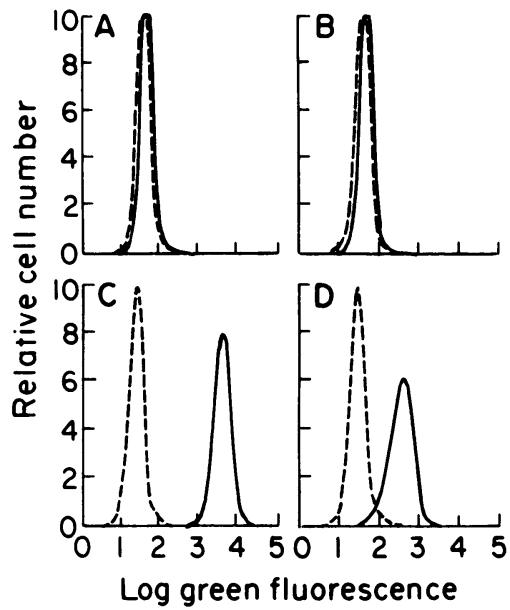

MEL cells; $(C)$ mAb 87.92.6 binding to R1.1 cells; and $(D)$ mAb HO13.4 binding to R1.1 cells. Solid lines indicate fluorescence profiles obtained after incubation with the individual mAbs; dashed lines indicate the binding of FITC-labeled antibody alone.

difference in the binding of these strains to MEL cell receptors. Therefore, these results indicate that sequences in type $3 \sigma 1$ previously shown to be important for HA (11) are also important for viral attachment to receptors on erythrocyte precursor cells.

$M E L$ cells do not express a receptor recognized by the antireovirus receptor antibody 87.92.6. Previous studies have demonstrated that many types of cells, including murine thymoma $\mathrm{R} 1.1$ cells, express a cellular receptor for T3D that is recognized by the antiidiotype $\mathrm{mAb} 87.92 .6$ (38), which was raised against the neutralizing anti- $\sigma 1 \mathrm{mAb}$ G5 (33). Given that mAb G5 resulted in some degree of inhibition of T3D binding to MEL cells (Fig. 3), we determined whether the T3D receptor recognized by $\mathrm{mAb}$ 87.92.6 is expressed on MEL cells. In these experiments, we used $\mathrm{mAb}$ concentrations that consistently demonstrated the binding of mAb 87.92.6 to R1.1 cells; however, the binding of $\mathrm{mAb}$ 87.92.6 to MEL cells could not be detected (Fig. 4). Therefore, MEL cells do not appear to express the type 3 reovirus receptor recognized by the antireceptor antibody 87.92 .6 .

\section{Discussion}

The selective recognition of cellular receptors by the mammalian reoviruses is an important determinant of cell and tissue tropism in an infected host and, thus, plays a major role in reovirus pathogenesis (3-6). In this study, we found that reovirus strain T3D, but not T1L, can infect erythrocyte precursor cells, and we determined that this property is mediated by the binding of T3D to cellular receptors. These results are consistent with previous studies that indicate type 1 and type 3 reovirus strains recognize unique receptors on different types of cells (7-9). However, this study represents the first demonstration that differences in reovirus tropism extend to cells of the erythroid lineage.

We conducted several experiments that suggest a domain of the type 3 reovirus cell-attachment protein, previously shown to be important for HA and binding to sialoglycophorin $\mathrm{A}$, is also important for the recognition of MEL cell receptors. By using $\mathrm{mAbs}$ that identify different functional domains of type 3 $\sigma 1$ (19), we determined that an mAb that inhibits T3D-mediated HA also inhibits the capacity of T3D to bind MEL cells. We also found that type 3 reovirus strains that are capable of infecting L cells, but do not agglutinate bovine and human erythrocytes and do not bind sialoglycophorin-coated plates (11), do not infect MEL cells. These experiments suggest that receptor molecules recognized by type 3 reovirus on some types of erythrocytes are similar to those on MEL cells; although, interestingly, murine erythrocytes are not agglutinated by type 3 reovirus strains (L. R. Dunnigan and T. S. Dermody, unpublished observations). Thus, it appears that the reovirus receptor expressed on MEL cells is not expressed on mature murine erythrocytes, or alternatively, receptors on murine erythrocytes can not be cross-linked by type 3 reovirus to produce HA.

Our results, which indicate that a $\sigma 1$ domain important for recognition of MEL cell receptors differs from that important for recognition of $L$ cell receptors, are exciting and suggest that different domains of the reovirus cell-attachment protein are used to initiate productive infections of different types of cells. The $\sigma 1$ protein has a head and tail morphology $(29,39-42)$. The region of sequence previously identified as important for HA (11), and now suggested to be important for binding to MEL cell receptors, resides in the $\sigma 1$ tail. Additional studies suggest that specific sequences important for binding to $L$ cell receptors are located in the $\sigma 1$ head (22-24). Therefore, it appears that sequences in both the $\sigma 1$ tail and the $\sigma 1$ head are involved in the attachment of reovirus to cellular receptors. These $\sigma 1$ sequences might interact cooperatively in reovirusreceptor recognition; alternatively, discrete receptor-binding regions of $\sigma 1$ might have greater relative importance depending on the type of receptor.

Type 3 reovirus is known to produce HA by binding to sialic acid-containing glycoproteins on the erythrocyte surface (10-12, 17, 43-45). Our finding that the capacity of type 3 reovirus to bind MEL cell receptors correlates with its capacity to agglutinate bovine and human erythrocytes and to bind sialoglycophorin suggests that the MEL cell receptor is a sialoglycoprotein. Previous reports have suggested that sialic acid is also important for type 3 reovirus binding to L cells $(43,44)$; however, the binding of reovirus to $\mathrm{L}$ cells does not correlate with HA and binding to sialoglycophorin-coated plates. Therefore, the configuration of sialic acid might differ on $L$ cells and MEL cells, or alternatively, other types of receptors (in addition to sialic acid-containing glycoproteins) might be bound by type 3 reovirus on $L$ cells.

In addition to our experiments that identified a discrete $\sigma 1$ domain important for the binding of T3D to MEL cells, we obtained results that suggest the T3D receptor on MEL cells differs from that identified on other types of cells. Previous studies have identified a cell surface receptor for T3D that is expressed on $L$ cells and $R 1.1$ cells using the antiidiotype $\mathrm{mAb}$ 87.92.6 (38). We show that reovirus can infect cells that lack the receptor identified by $\mathrm{mAb} 87.92 .6$, as has been demonstrated in an earlier study using primary cultures derived from mouse brain (46). However, the mechanism of viral attachment to these primary culture cells has not been elucidated. Therefore, it will be of interest to determine whether the attachment of type 3 reovirus to cells that do not express the cellular 
receptor identified by $\mathrm{mAb} 87.92 .6$ is mediated by a $\sigma 1$ domain important for attachment to MEL cells.

The experiments presented in this report demonstrate that the binding of type 3 reovirus to erythrocyte precursor cells by a $\sigma 1$ domain important for HA leads to productive infection of these cells. Since many viruses have the capacity to bind erythrocyte membrane proteins (12), it is conceivable that acute or persistent infection of preerythrocytes might lead to the transient anemia observed with infections caused by many viruses (47). Thus, our study raises the possibility that reovirus infection of erythrocyte precursor cells might serve as a useful model for the study of alterations in hematopoiesis associated with viral infection. Moreover, given that a $\sigma 1$ domain important for HA appears to mediate the attachment of reovirus to MEL cells, it is possible that model peptides or analogues corresponding to this domain will be highly selective for erythrocyte precursors or mature erythrocytes. Therefore, these data might lead to a novel approach of targeting preerythrocytes for gene therapy or selective chemotherapy.

\section{Acknowledgments}

We express our appreciation to Patricia Seitz for secretarial support and Marilyn Sutcliffe for technical assistance. We are grateful to Alan Pickard and Bruce Greig for performing flow cytometry, Mark Greene for generously providing mAb 87.92.6 and Mary Margaret Peel for graphics. We also thank Mark Denison, David Karzon, Sanford Krantz, and Peter Wright for reviews of the manuscript.

This work was supported by a Merit Review Grant from the Department of Veterans Affairs (D. H. Rubin), National Multiple Sclerosis Society Grant RG2093-A-1 (J. A. Cohen), and Public Health Service Awards NS-01284 from the National Institute of Neurologic Diseases and Stroke (J. A. Cohen), and AI-28503 (W. V. Williams) and AI00865 (T. S. Dermody) from the National Institute of Allergy and Infectious Diseases. Support to J. D. Wetzel and T. S. Dermody was also provided by the Elizabeth B. Lamb Center for Pediatric Research.

\section{References}

1. Mims, C. A., and D. O. White. 1984. Viral Pathogenesis and Immunology. Blackwell Scientific Publications Ltd., Oxford, England. 297 pp.

2. Tyler, K. L., and B. N. Fields. 1990. Reoviruses. In Fields Virology. 2nd ed. B. Fields and D. Knipe, editors. Raven Press, Ltd., New York. 1307-1328.

3. Weiner, H. L., D. Drayna, D. R. Averill, Jr., and B. N. Fields. 1977. Molecular basis of reovirus virulence: role of the S1 gene. Proc. Natl. Acad. Sci. USA. 74:5744-5748.

4. Weiner H. L., M. L. Powers, and B. N. Fields. 1980. Absolute linkage of virulence with central nervous system cell tropism of reovirus to hemagglutinin. J. Infect. Dis. 141:609-616.

5. Onodera, T., A. Toniolo, U. R. Ray, A. B. Jenson, R. A. Knazek, and A. L. Notkins. 1981. Virus-induced diabetes mellitus. XX. Polyendocrinopathy and autoimmunity. J. Exp. Med. 153:1457-1473.

6. Rubin, D. H., M. A. Eaton, and A. O. Anderson. 1986. Reovirus infection in adult mice: the virus hemagglutinin determines the site of intestinal disease. Microb. Pathog. 1:79-87.

7. Epstein, R. L., M. L. Powers, R. B. Rogart, and H. L. Weiner. 1984. Binding of iodine-125 labelled reovirus to cell surface receptors. Virology. 133:46-55.

8. Fontana, A., and H. L. Weiner. 1988. Interaction of reovirus with cell surface receptors. II. Generation of suppressor T cells by the hemagglutinin of reovirus type 2. J. Immunol. 125:2660-2665.

9. Weiner, D. B., K. Girard, W. V. Williams, T. McPhillips, and D. H. Rubin. 1988. Reovirus type 1 and type 3 differ in their binding to isolated intestinal epithelial cells. Microb. Pathog. 5:29-40.

10. Gentsch, J. R., and A. F. Pacitti. 1987. Differential interaction of reovirus type 3 with sialylated receptor components on animal cells. Virology. 161:245248.

11. Dermody, T. S., M. L. Nibert, R. Bassel-Duby, and B. N. Fields. 1990. A $\sigma 1$ region important for hemagglutination by serotype 3 reovirus strains. J. Virol. 64:5173-5176.

12. Burness, A. T. H. 1981. Glycophorin and sialylated components as receptors for viruses. In Virus Receptors. Part 2. Receptors and Recognition. K. Lonberg-Holm, and L. Philipson, editors. Chapman \& Hall, Ltd., London. 63-84.

13. Weiner, H. L., K. A. Ault, and B. N. Fields. 1980. Interaction of reovirus with cell surface receptors. I. Murine and human lymphocytes have a receptor for the hemagglutinin of reovirus type 3. J. Immunol. 124:2143-2148.

14. Greene, M. I., and H. L. Weiner. 1980. Delayed hypersensitivity in mice infected with reovirus. II. Induction of tolerance and suppressor T cells to viral specific gene products. J. Immunol. 125:283-287.

15. Lee, P. W. K., E. C. Hayes, and W. K. Joklik. 1981. Protein $\sigma 1$ is the reovirus cell attachment protein. Virology. 108:156-163.

16. Weiner, H. L., R. F. Ramig, T. A. Mustoe, and B. N. Fields. 1978. Identifcation of the gene coding for the hemagglutinin of reovirus. Virology. 86:581584.

17. Paul, R. W., and P. W. K. Lee. 1987. Glycophorin is the reovirus receptor on human erythrocytes. Virology. 159:94-101.

18. Weiner, H. L., and B. N. Fields. 1977. Neutralization of reovirus: the gene responsible for the neutralization antigen. J. Exp. Med. 146:1305-1310.

19. Burstin, S. J., D. R. Spriggs, and B. N. Fields. 1982. Evidence for functional domains of the reovirus type 3 hemagglutinin. Virology. 117:146-155.

20. Nagata, L., S. A. Masri, R. T. Pon, and P. W. K. Lee. 1987. Analysis of functional domains on reovirus cell attachment protein $\sigma 1$ using cloned $\mathrm{S} 1$ deletion mutants. Virology. 160:162-168.

21. Yeung, M. C., M. J. Gill, S. S. Alibhai, M. S. Shahrabadi, and P. W. K. Lee. 1989. The cell attachment proteins of type 1 and type 3 reovirus are differentially susceptible to trypsin and chymotrypsin. Virology. 170:62-70.

22. Williams, W. V., H. R. Guy, D. H. Rubin, F. Robey, J. N. Myers, T. Kieber-Emmons, D. B. Weiner, and M. I. Greene. 1988. Sequences of the cell-attachment sites of reovirus type 3 and its anti-idiotypic/antireceptor antibody: modeling of their three-dimensional structures. Proc. Natl. Acad. Sci. USA. 85:6488-6492.

23. Duncan, R., D. Horne, J. E. Strong, G. Leone, R. T. Pon, M. C. Yeung, and P. W. K. Lee. 1991. Conformational and functional analysis of the c-terminal globular head of the reovirus cell attachment protein. Virology. 182:810-819.

24. Turner, D. L., R. Duncan, and P. W. K. Lee. 1992. Site-directed mutagenesis of the c-terminal portion of reovirus protein $\sigma \mathrm{l}$ : evidence for a conformationdependent receptor binding domain. Virology. 186:219-227.

25. Ross, J., J. Glelen, S. Packman, Y. Ikawa, and P. Leder. 1974. Globin gene expression in cultured erythroleukemic cells. J. Mol. Biol. 87:697-714.

26. Brown, E. G., M. L. Nibert, and B. N. Fields. 1983. The L2 gene of reovirus serotype 3 controls the capacity to interfere, accumulate deletions and establish persistent infection. In Double-Stranded RNA Viruses. R. W. Compans and D. H. L. Bishop, editors. Elsevier Science Publishing Co., Inc., New York. 275-287.

27. Coombs, K. C., B. N. Fields, and S. C. Harrison. 1990. Crystallization of the reovirus type 3 Dearing core: crystal packing is determined by the $\lambda 2$ protein. J. Mol. Biol. 215:1-5.

28. Dermody, T. S., M. L. Nibert, R. Bassel-Duby, and B. N. Fields. 1990 Sequence diversity in $S 1$ genes and $S 1$ translation products of 11 serotype 3 reovirus strains. J. Virol. 64:4842-4850.

29. Furlong, D. B., M. L. Nibert, and B. N. Fields. 1988. Sigma 1 protein of mammalian reoviruses extends from the surfaces of viral particles. J.Virol. 62:246-256.

30. Rubin, D. H., M. J. Kornstein, and A. O. Anderson. 1985. Reovirus serotype 1 intestinal infection: a novel replicative cycle with ileal disease. J. Virol. 53:391-398.

31. Smith, R. E., H. J. Zweerink, and W. K. Joklik. 1969. Polypeptide components of virions, top component and cores of reovirus 3. Virology. 39:791-810.

32. Greenwood, F. C., W. M. Hunter, and J. S. Glover. 1963. The preparation of I-131-labelled human growth hormone of high specific radioactivity. Biochem. J. 89:114-123.

33. Noseworthy, J. H., B. N. Fields, M. S. Dichter, C. Sobotka, E. Pizer, L. L. Perry, J. T. Nepom, and M. I. Greene. 1983. Cell receptors for the mammalian reovirus. I. Syngeneic monoclonal anti-idiotypic antibody identifies the cell surface receptor for reoviruses. J. Immunol. 131:2533-2538.

34. Marshak-Rothstein, A., P. Fink, T. Gridley, D. H. Raulet, M. J. Bevan, and M. L. Gefter. 1979. Properties and applications of monoclonal antibodies directed against determinants of the thy-1 locus. J. Immunol. 122:2491-2497.

35. Ernst, G., and A. J. Shatkin. 1985. Reovirus hemagglutinin mRNA codes for two polypeptides in overlapping reading frames. Proc. Natl. Acad. Sci. USA. 82:48-52.

36. Jacobs, B. L., and C. E. Samuel. 1985. Biosynthesis of reovirus-specified polypeptides: the reovirus S1 mRNA encodes two primary translation products. Virology. 143:63-74.

37. Sarkar, G., J. Pelletier, R. Bassel-Duby, A. Jayasuriya, B. N. Fields, and N. 
Sonenberg. 1985. Identification of a new polypeptide coded by reovirus gene S1. J. Virol. 54:720-725.

38. Co, M. S., G. N. Gaulton, B. N. Fields, and M. I. Greene. 1985. Isolation and biochemical characterization of the mammalian reovirus type 3 cell-surface receptor. Proc. Natl. Acad. Sci. USA. 82:1494-1498.

39. Banerjea, A. C., K. A. Brechling, C. A. Ray, H. Erikson, D. J. Pickup, and W. K. Joklik. 1988. High-level synthesis of biologically active reovirus protein $\sigma 1$ in a mammalian expression vector system. Virology. 167:601-612.

40. Nibert, M. L., T. S. Dermody, and B. N. Fields. 1990. Molecular structure of the reovirus cell-attachment protein: a model for the domain organization of o1. J. Virol. 64:2976-2989.

41. Fraser, R. D. B., D. B. Furlong, B. L. Trus, M. L. Nibert, B. N. Fields, and A. C. Steven. 1990. Molecular structure of the reovirus cell-attachment protein: correlation of computer-processed electron micrographs with sequence-based predictions. J. Virol. 64:2990-3000.

42. Duncan, R., D. Horne, L. W. Cashdollar, W. K. Joklik, and P. W. K. Lee.
1990. Identification of conserved domains in the cell attachment proteins of the three serotypes of reovirus. Virology. 174:339-409.

43. Armstrong, G. D., R. W. Paul, P. W. K. Lee. 1984. Studies on reovirus receptors of $L$ cells: virus binding characteristics and comparison with reovirus receptors of erythrocytes. Virology. 138:37-48.

44. Gentsch, J. R., and A. F. Pacitti. 1985. Effect of neuraminidase treatment of cells and effect of soluble glycoproteins on type 3 reovirus attachment to murine L cells. J. Virol. 56:345-364.

45. Paul, R. W., A. H. C. Choi, and P. W. K. Lee. 1989. The $\alpha$-anomeric form of sialic acid is the minimal receptor determinant recognized by reovirus. Virology. 172:382-385.

46. Dichter, M. A., H. L. Weiner, B. N. Fields, G. Mitchell, J. Noseworthy, G. Gaulton, and M. Greene. 1986. Antiidiotypic antibody to reovirus binds to neurons and protects from viral infection. Ann. Neurol. 19:555-558.

47. Jansson, L. T., S. Kling, and P. R. Dallman. 1986. Anemia in children with acute infections seen in a primary care pediatric outpatient clinic. Pediatr. Infect. Dis. 5:424-427. 